\title{
The Development of Batak and Malay Batik Motif Stilation in Improving the Creative Industry in Indonesia
}

DOI: https://doi.org/10.47175/rissj.v2i4.323

\author{
| Farihah $^{1^{*}}$ | Dina Ampera ${ }^{2}$ | Halimul Bahri ${ }^{3}$ | Yudhistira Anggraini ${ }^{4}$ | \\ | Bakhrul Khair Amal' |
}

1,2,3,4 Department of Family

Welfare Education, Faculty of

Technology, Universitas

Negeri Medan, Indonesia

${ }^{5}$ Faculty of Social Science, Universitas Negeri Medan, Indonesia

*harisman@umsu.ac.id

\begin{abstract}
The purpose of this study was to determine the stylization of Batak and Malay batik motifs by developing the shape of a typical Batak batik motif with a typical Malay batik motif and to determine the process of developing a Batak and Malay batik motif design. The target of the research is to create and produce designs of stylized Batak and Malay batik motifs and to conduct batik trials on fabrics with motifs that have been developed, so as to produce textile products in the form of a blend of batik cloth between two tribes in North Sumatra. The research method used is the development research method (R\&D). The research model is the IDI (instructional, development, Institute) development model, which includes three stages: define, develop, evaluate. The define stage includes: identifying problems, needs analysis, motive characteristic analysis, design concept analysis. The develop stage includes: development of motif designs and validation of product results by experts (validators). The results showed that Batak and Malay batik products deserve to be developed as a creative industry. The first validation gave a score of 0.89 , the second validation got a score of 0.86 and the third validation obtained a score of 0.94 . The average value of the validation results is 0.89 , so the results of research on the development of stylized Batak and Malay batik motifs are included in the appropriate category and can improve the creative industry in Indonesian. KEYWORDS

Batak motif; Malay motif; creative industry
\end{abstract}

\section{INTRODUCTION}

North Sumatra Province is one of the provinces in Indonesia that has textile craft products that are well known by the Indonesian people, namely Ulos woven (Sihombing \& Sihombing, 2018). Ulos is a typical Batak weave whose woven motifs describe the tribes in North Sumatra (Butar-Butar, 2018). The motif contains a moral message and meaning includes social status of the community, rules in the family (Tambunan, Lores, \& Rosalina, 2019). Apart from weaving, North Sumatra also developed innovative textile works in the form of batik, including written and stamped batik.

North Sumatra batik takes inspiration from the Ulos woven motif. North Sumatra batik craftsmen developed their motif ideas which were sourced from this typical Batak woven, so that various types of North Sumatra batik emerged in the hands of creative craftsmen. This North Sumatra batik was adopted from seven motifs, namely 1) Hari Hara Sundung Dilangit motif, which is a typical motif of the Toba Batak tribe; 2) Mataniari motif, which is typical of Mandailing; 3) Pani Patunda motif from Simalungun; 4) Gorga Sitompi, 5) 
The Ants Motive; 6) Bamboo Shoots Motif; and 7) The Evening Duck Motive which is a typical Malay motif (Rajagukguk, 2020).

Based on ethnic groups, the population of North Sumatra consists of indigenous people, indigenous immigrants and foreigners. The indigenous people are: ethnic Malays, Batak Karo, Simalungun, Fak-fak/Dairi, Batak Toba, Mandailing, and Nias. The indigenous immigrant are ethnic groups: Javanese, Sundanese, Balinese, Ambonese, Minahasa, Banjar, Palembang, Riau, Minangkabau and others, while the foreign residents are Arabs, Indians, Chinese and other nations (Arifin, Ananta, Utami, Handayani, \& Pramono, 2015; Jaya, 2020). Approximately $80 \%$ of North Sumatra residents live in villages as farmers and others live in cities as traders, employees, craftsmen and so on (Sihite, 2021).

Philosophically, the Malay Batak Batik that will be developed refers to the motto of the United State of the Republic of Indonesia (NKRI) which reads "Bhineka Tungga Ika" which means that although we are different, the essence is still one. Based on the motto of the State, two ethnic batik motifs were developed in North Sumatra, namely Batak and Malay.

One of the efforts to strengthen national relations is to produce batik products that are a combination of Batak batik motifs and Malay batik motifs so as to give birth to a relationship that can strengthen inter-ethnic relations so as to create Bhineka Tunggal Ika through a work of art. The development of the North Sumatra Malay Batak motif refers to the production process according to the standards and procedures applicable in the textile industry.

\section{RESEARCH METHODS}

Research Systematics

Research and Development method used in this study to produce certain products, and increase the effectiveness of these products (Sugiyono, 2009). Seels \& Richey (1994) define Research and Development as a systematic study of the design, development and evaluation of programs, processes and products that must meet the criteria of validity, practicality, and effectiveness. The research location for the development of stylized motifs of Batak and Malay batik was carried out at the Fashion Design Education Study Program, Department of Family Welfare Education, Faculty of Engineering, Universitas Negeri Medan. The development model used is the IDI (Instructional Development Institute) model. The IDI model establishes the principles of a systems approach which includes three stages, namely define, develop, and evaluate.

\section{Development Procedure}

The development procedure used is an elaboration of the modified development model of the researcher that is tailored to the needs. The procedure for developing the Malay Batak Batik Motif can be seen in the Figure 1:

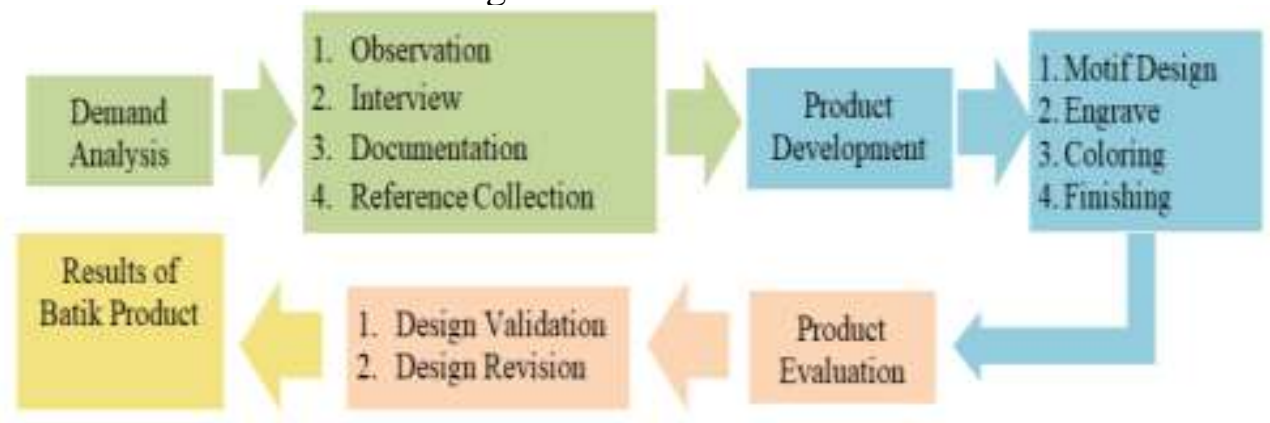

Figure 1. Development Procedure (modified from Trianto, 2012) 


\section{Define}
a. Observation
Observation activities were carried out to see the development of the types and forms of batik motifs produced by the North Sumatran batik industry.
b. Interview
Interview activities were carried out with the industry to obtain information related to the motifs used, the source of the motif ideas, the raw materials used for the batik process.
c. Documentation
Documentation is carried out during the interview process at the industrial location, where pictures related to the research are collected to support the ideas and ideas in the application of this development research.
d. Reference collection
Collection of references in the form of related research and reference sources in the form of similar supporting books.

\section{Product Development}

At this stage the researchers developed the initial product in the form of Batak and Malay batik motifs.

a. Design of North Sumatran Batak and Malay batik motifs

The selection of Batak batik motifs and Malay batik motifs will be developed into Malay Batak batik motifs.

b. The layout design of the North Sumatran Batak and Malay batik motifs After the motif is selected, it is continued with the process of making a composition of new shapes from the previous motif or continuing to use the original motif by changing the position, position or color and so on.

c. Design of motif coloring using CorelDraw version X17 software

After the design layout is complete, a coloring test is carried out with CorelDraw X17 software, making it faster and easier to choose the colors that will be set during the batik process.

d. Transferring the motif to the fabric.

After the coloring process is done, then enter the stage of transferring the motif onto the fabric to be batik.

e. The process of batik on cloth

After the coloring process is done, then enter the stage of transferring the motif onto the fabric to be batik.

f. Finishing

After the batik process is done on the cloth, then the final stage is like washing to remove the dye on the cloth, so it doesn't damage the wearer's skin and finishing other things in accordance with industrial SOPs.

\section{Evaluate}

The evaluation is carried out by experts who have competencies and fields according to their fields of expertise, intended to evaluate the resulting Malay Batak batik products.

\section{Data Analysis}

After the instrument is valid, then the product data validity is developed using quantitative descriptive analysis, namely by analyzing quantitative data obtained from product 
validation questionnaires given to experts. Summing up the scores of each validator for all indicators. Entering statistical data into the following formula by Aiken (1985):

$\mathrm{V}=\sum \mathrm{s} /[\mathrm{n}(\mathrm{c}-1)]$

Where: $\mathrm{S}=\mathrm{r}-\mathrm{lo}, \mathrm{lo}=$ lowest validity assessment value $(\mathrm{lo}=1), \mathrm{c}=$ highest validity assessment value $(\mathrm{c}=5), \mathrm{r}=$ the value provided by the validator

The results of the calculation of the Aiken formula range from 0 to 1 , the number 0.6 is interpreted as having a fairly high coefficient (Azwar, 2014) then the Validation value (V) 0.6 and above is stated in the valid category.

\section{RESULTS AND DISCUSSION}

\section{Define}

\section{Observation result}

Observation activities were carried out to see the development of the types and forms of batik motifs produced by the North Sumatra batik industry. The results obtained when conducting observations include the forms of the North Sumatra Batak motifs and the forms of the North Sumatra Malay batik motifs.

\section{Interview Result}

Interviews were carried out with the industry to obtain information related to the motifs used, the source of the motif ideas, and the raw materials used for the batik process. The information obtained during the interview process were: (1) The source of the motive idea for this research was taken from the Batak motif, namely the Gorga Boraspati motif, which is shaped like a lizard, which means wisdom and wealth; (2) The Ulos Sadum motif is shaped like a rhombus and there are dots filled in the area of the motif, having a symbolic meaning of joy and motivation in daily activities; (3) Rattan motifs are shaped like lines found on Ulos Ragi Hotang which means the strength of the bond between two couples (for married couples). While the idea of the Malay motif is taken from the bamboo shoot motif and the stylized motif from bamboo shoots that was developed in this batik product, which has the meaning of showing humility. The raw material used in Batak and Malay batik is $100 \%$ cotton and the motif decoration is taken from the ulos motif.

\section{Documentation Result}

The results of the documentation obtained in the form of photos of Batak batik products from North Sumatra and Malay batik. In addition, there are also photos of motifs used by North Sumatra batik craftsmen.

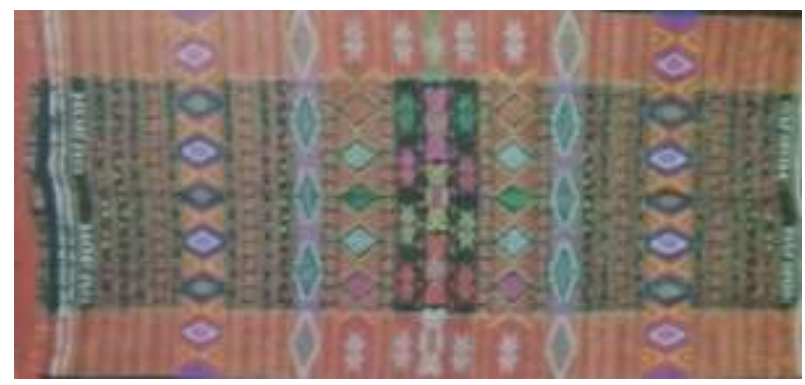

Figure 2. Ulos Sadum motif (Sitompul, 2009) 


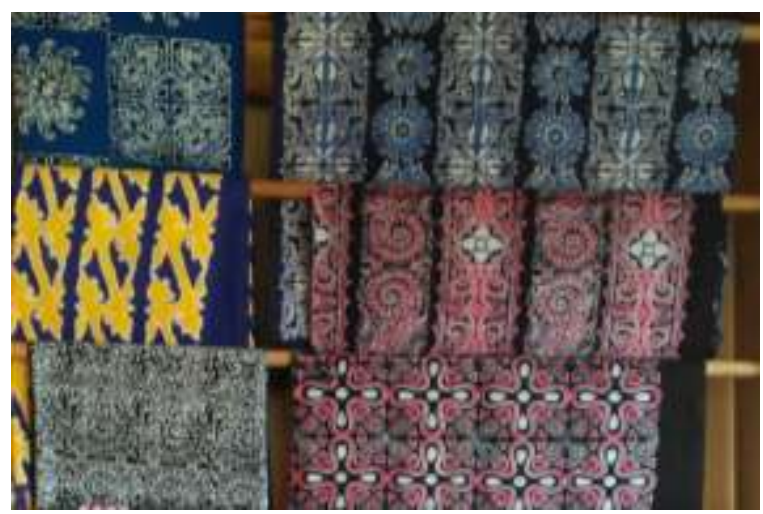

Figure 3. Some batik works in Medan, North Sumatra (personal documentation, 2021)

\section{Reference Collection Results}

Collection of references in the form of related research and reference sources in the form of books and journals include Kusumawardhani (2012); Sitompul (2009); Hami \& Suryawan (2009); BBKB (2018); Parmono (2013); Widadi (2019); Prasetyo \& Singgih (2016); Amaris (2020); Kusmayadi (2020); Wardoyo (2019); www.disperindag.sumut.go.id

\section{Develop}

The stage where the researcher develops the initial product in the form of Batak and Malay batik motifs.

\section{The design of the North Sumatra Malay Batak batik motif}

The selection of Batak batik motifs and Malay batik motifs will be developed into Malay Batak batik motifs.

\section{Layout design for North Sumatra Batak and Malay batik motifs}

The author designs several forms of motifs produced by stylization techniques, then arranges the layout and composition of the motifs, so as to get the shape of the motif design that will be used. The design of the motif still refers to the basic shape of the Batak and Malay motifs before the stylization is carried out. This is done in order to keep the meaning of each motif unchanged.
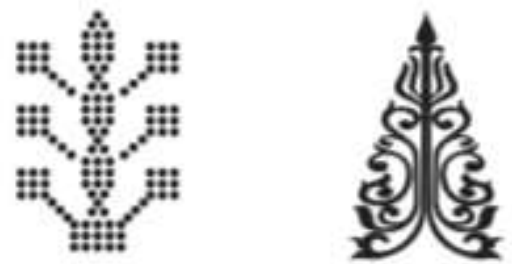

Figure 4. The Batak Gorga motif (left) and the Malay Pucuk Rebung motif (right) (personal documentation, 2021)

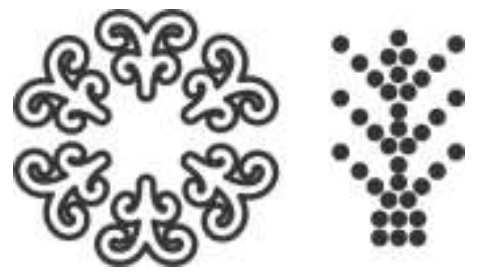




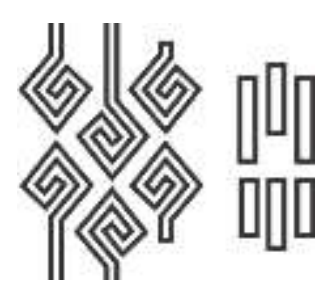

Figure 5. Stylization of Batak and Malay motifs (personal documentation, 2021)

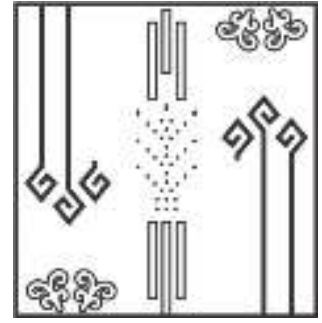

(a) Babam Motif

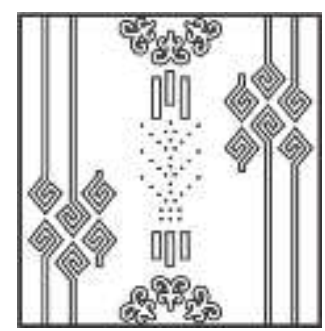

(b) Babayu Motif

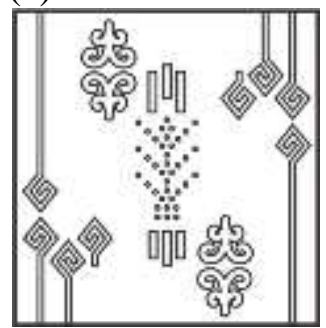

(c) Bamel Motif

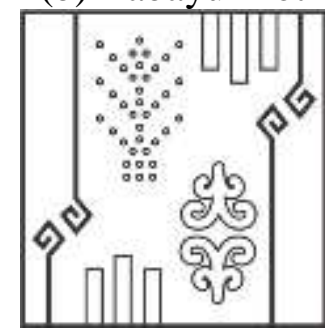

(d) Bataku Motif

Figure 6. Motive layout process (personal documentation, 2021)

The Babam motif design layout consists of two arrangement of the shoots of bamboo shoots in the upper right corner and the lower left corner. The three arrangements of the Ulos Sadum motif are on the left and right, while the Gorga Boraspati motif is placed in the middle between the Rattan motifs consisting of three lines. The Babayu motif design layout consists of six arrangements of Ulos Sadum motifs on the left and right. The Gorga Boraspati motif is found in the middle between the three shoots of bamboo shoots and rattan. Bamel's design layout consists of four Ulos Sadum motifs on the left and right. Two shoots of bamboo shoots in the upper left corner and the lower right corner. The Gorga Boraspati motif is in the middle between three rows of Rattan motifs. The design layout of the Bataku motif consists of two shoots of bamboo shoots on the bottom right and the Gorga Boraspati motif on the top left. Two Ulos Sadum and rattan motifs are found in the lower left and upper right corners.

\section{Design of motif coloring using CorelDraw X 17 software}

The appeal of a batik product is to show the balance of value and combination of a selected color. In batik products, color is an element that is considered in addition to motifs. After the layout of the motifs is generated, a trial of coloring is carried out with Coreldraw X 17 software. This process is carried out to simplify the process of coloring the batik cloth and reduce the risk of errors when carrying out the dyeing process directly on the batik cloth. 


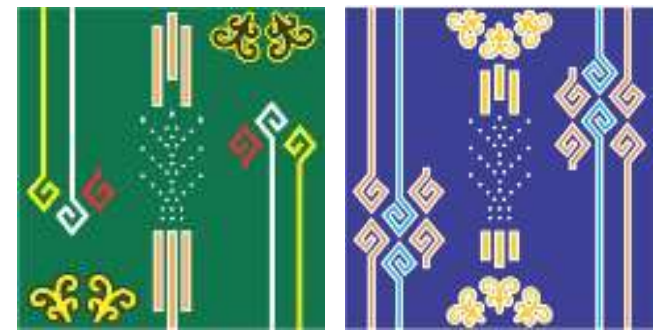

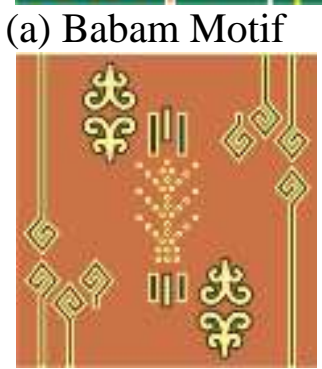

(c) Bamel Motif (b) Babayu Motif

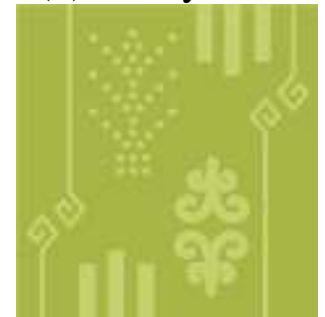

(d) Bataku Motif

Figure 7. Coloring Design (personal documentation, 2021)

The design of the Babam motif coloring uses five color combinations including dark green base colors, yellow, white and red Ulos Sadum motifs. The color of the bamboo shoots motif is black and yellow. Rattan motif in orange color and Gorga Boraspati motif in white. The design for coloring the Babayu motif uses five color combinations, including a dark blue base color, a yellow bamboo shoot and rattan motif. The color of the Ulos Sadum motif is light blue and orange, while the color of the Gorga Boraspati motif is white. Furthermore, the Bamel motif coloring design consists of three color combinations including the basic color brown, the Ulos Sadum and Rattan motifs in black, the Pucuk Rebung and Gorga Boraspati motifs in light yellow. The design of the Baku motif coloring consists of one color using a green gradation system.

\section{Transfer of fabric motifs}

After going through the process of developing a batik motif design, a motif design is chosen to be carried out on the fabric. The motif chosen is the Babayu batik motif (Figure 7 part 2). In the process of transferring motifs, the thing that must be considered when imprinting (painting motifs on cloth using special materials) is that the motif lines should not be interrupted so that during the coloring process the colors for each motif are in their respective places.

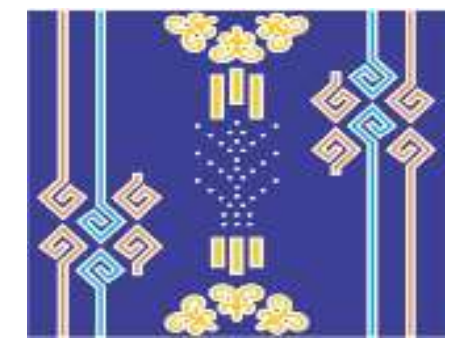

Figure 8. Selected Motif (Babayu) (personal documentation, 2021)

\section{Coloring Process}

At this stage, we determine the suitability of each color that has been selected during the color design process. In addition, we also prepare coloring materials and adjust the amount of each color used. 
Figure 9. Colors used in the Batik Process (personal documentation, 2021)

As a guide in producing a predetermined color, the image of the color circle below can be used as a reference to produce the selected color (Figure 10). This is done in order to save time when finding the desired color match.

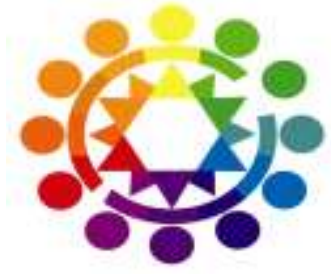

Figure 10. Color circle (Saad, 2006)

\section{Coloring Process}

The final stage of the batik process is removing the wax, binding the batik dye and washing to clean the batik material from adhering impurities and removing unnecessary colors so that they do not stick to the skin when touched.

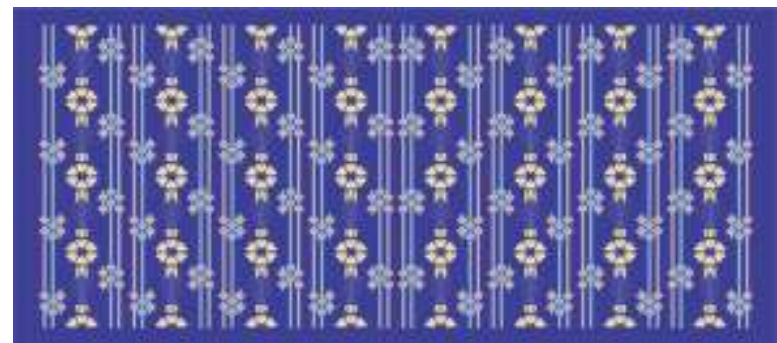

Figure 11. The final result of batik stylization with Batak and Malay motifs (personal documentation, 2021)

\section{Validation Result}

Table 1. Product Validation of Batak and Malay Batik Motif Stylization

\begin{tabular}{|c|c|c|c|c|c|c|c|c|c|c|c|c|c|c|c|c|c|c|c|c|c|c|}
\hline & \multicolumn{3}{|c|}{$\begin{array}{l}\text { Design } \\
\text { Aspect }\end{array}$} & & & \multicolumn{4}{|c|}{$\begin{array}{l}\text { Display } \\
\text { Aspect }\end{array}$} & & \multicolumn{4}{|c|}{$\begin{array}{l}\text { Function } \\
\text { al Aspect }\end{array}$} & \multicolumn{3}{|c|}{$\begin{array}{l}\text { Color } \\
\text { Aspect }\end{array}$} & $\begin{array}{l}\text { Balance } \\
\text { Aspect }\end{array}$ & \multirow[t]{2}{*}{$\begin{array}{l}\sum_{\mathbf{S}} \\
\mathbf{S}\end{array}$} & \multirow[t]{2}{*}{$\begin{array}{l}\mathbf{N} \\
(c-1)\end{array}$} & \multirow[t]{2}{*}{$\begin{array}{l}\text { Value } \\
\text { of } V\end{array}$} & \multirow[t]{2}{*}{$\begin{array}{l}\text { Infor- } \\
\text { mation }\end{array}$} \\
\hline & 1 & 2 & 3 & 4 & 5 & 6 & 7 & 8 & 9 & $\begin{array}{l}1 \\
0\end{array}$ & $\begin{array}{l}1 \\
1 \\
\end{array}$ & $\begin{array}{l}1 \\
2 \\
\end{array}$ & $\begin{array}{l}1 \\
3 \\
\end{array}$ & $\begin{array}{l}1 \\
4 \\
\end{array}$ & $\begin{array}{l}1 \\
5 \\
\end{array}$ & $\begin{array}{l}1 \\
6 \\
\end{array}$ & $\begin{array}{l}1 \\
7\end{array}$ & $\begin{array}{lll}1 & 1 & 2 \\
8 & 9 & 0\end{array}$ & & & & \\
\hline V 1 & 4 & 4 & 5 & 5 & 4 & 4 & 5 & 5 & 4 & 5 & 4 & 5 & 4 & 5 & 4 & 5 & 4 & 45 & 89 & 80 & 0.89 & V \\
\hline V 2 & 5 & 5 & 5 & 4 & 4 & 5 & 5 & 5 & 4 & 5 & 5 & 5 & 4 & 5 & 5 & 4 & 4 & 55 & 93 & 80 & 0.86 & V \\
\hline V 3 & 5 & 5 & 4 & 5 & 4 & 4 & 5 & 4 & 5 & 3 & 4 & 4 & 5 & 4 & 4 & 4 & 4 & 34 & 85 & 80 & 0.94 & V \\
\hline$\overline{\mathrm{Ave}}$ & & & & & & & & & & & & & & & & & & & & & 0.89 & $\mathrm{~V}$ \\
\hline
\end{tabular}

The product validation of the development of the Batak and Malay stylized motifs obtained the first validation value with a score of 0.89 which was included in the valid category. The second validation value obtained a score of 0.86 is also included in the valid category. Likewise with the third validation value obtained a value of 0.94 included in the valid category. The average result of the assessment from the three experts was 0.89 , meaning that the Batak and Malay batik products developed were valid and feasible to be developed in accordance with the opinion of Azwar (2014). 


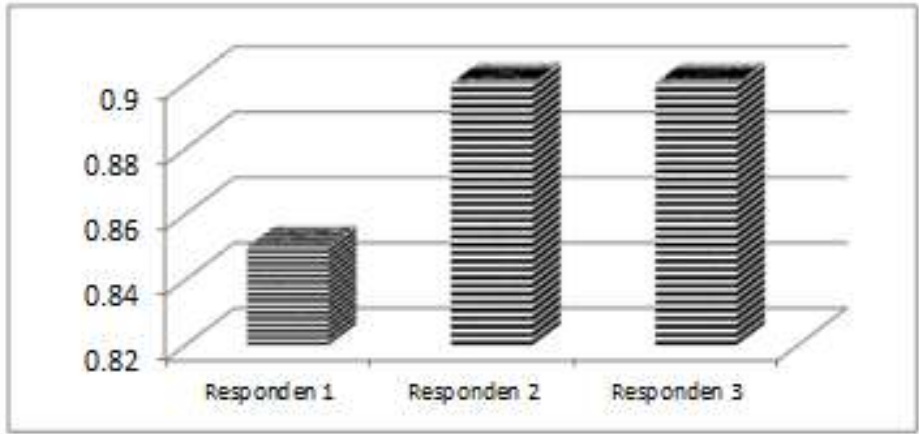

Figure 12. Design aspect assessment values

Figure 12 reveals that the first respondent's assessment of this design aspect scored 0.85; second and third respondents with a score of 0.90 . Figure 13 reveals that respondent 1 gave an assessment of the appearance of Batak and Malay batik with a score of 0.95; Respondent two gave an assessment score of 0.90 and respondent three 0.80 .

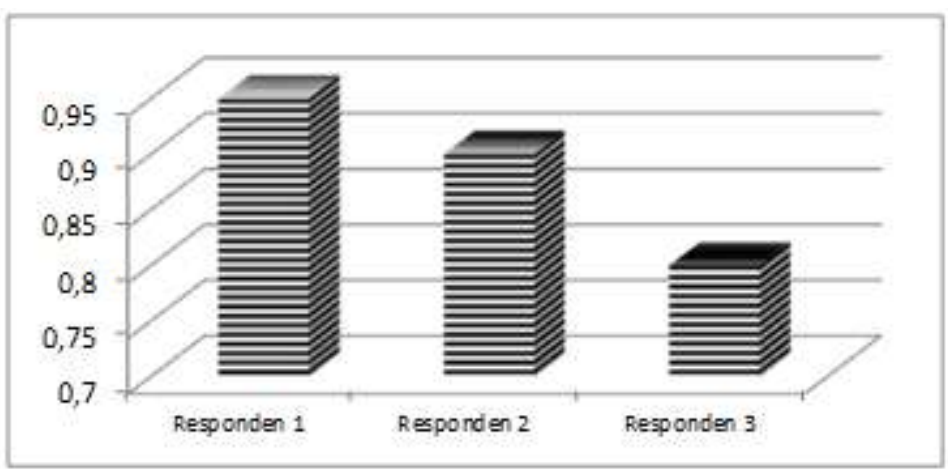

Figure 13. Display aspect assessment values

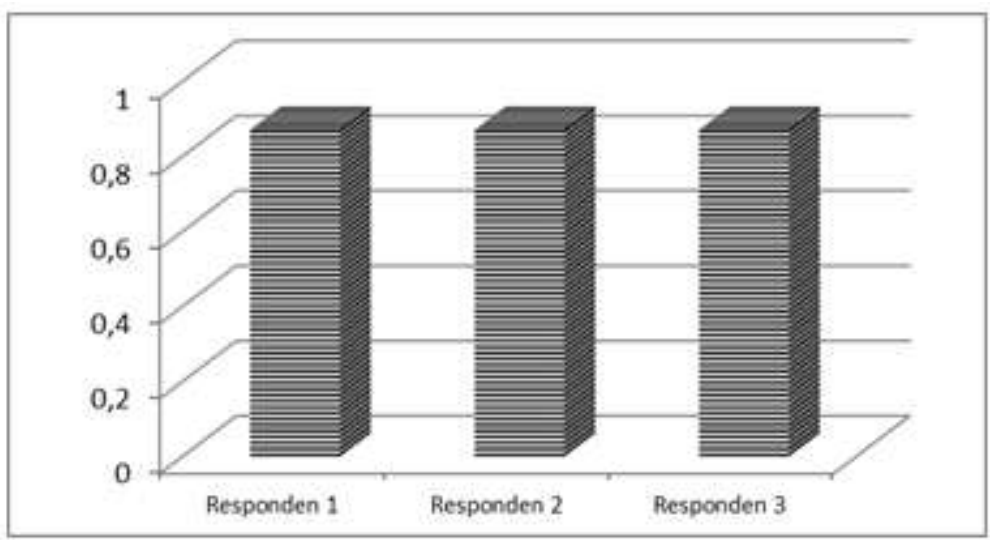

Figure 14. Functional aspect assessment values

In the functional aspect of developing Batak and Malay batik motifs, the first, second and third respondents both gave an assessment with a score of 0.87 (Figure 14). The assessment of the first and second respondents on the color aspect used in the development of the Batak and Malay batik motifs is the same as a score of 0.83 , while the third respondent gives an assessment score of 0.91 (Figure 15). The assessment of the balance aspect of the first respondent gave a score of 0.83 ; the second respondent gave a score of 1 and the third respondent gave a score of 0.75 (Figure 16). 


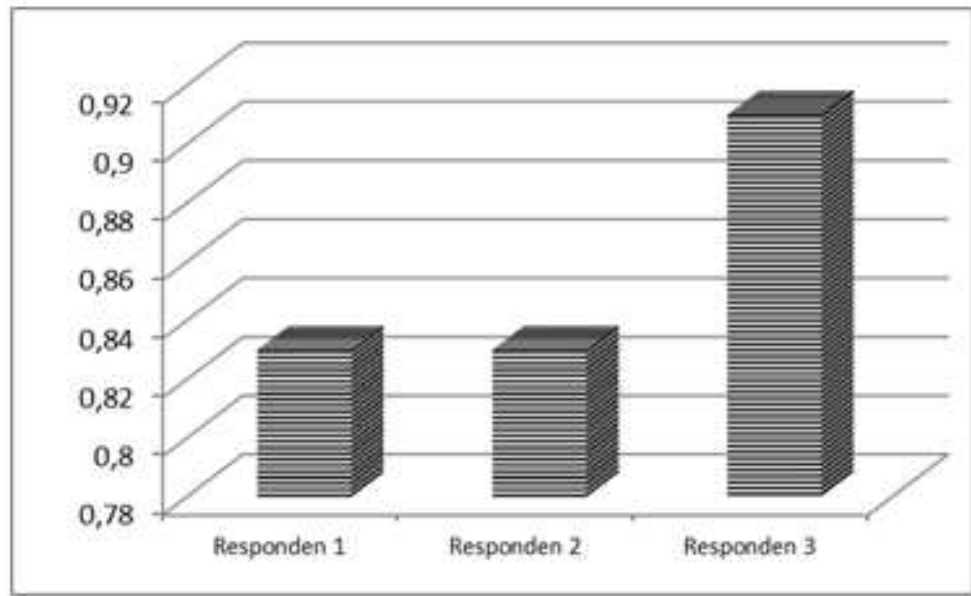

Figure-15. Color aspect assessment values

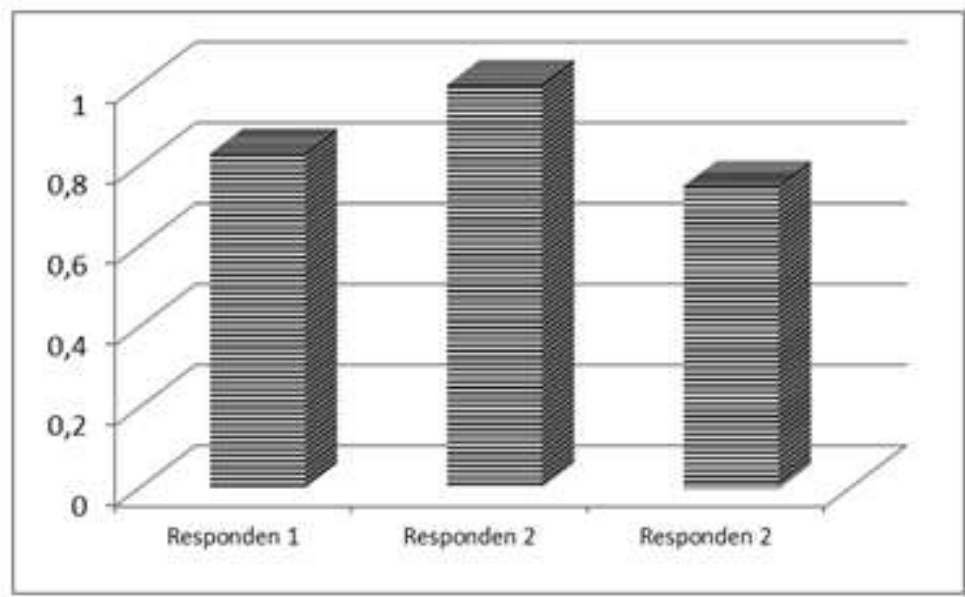

Figure-16. Balance aspect assessment values

Based on the research, a Batak and Malay batik product has been successfully created. The results of the products that have been assessed through the product validity sheet obtained validation data on the development of stylized Batak and Malay batik motifs with the highest validation value of 0.94 and the lowest validation value of 0.86 . The average value of the validation of Batak and Malay batik products was obtained with a value of 0.89. In general, it can be said that the development of the stylized motifs of the Batak and Malay motifs of North Sumatra deserves to be developed in accordance with the opinion of Azwar (2014). Thus, the development of the stylized Batak and Malay batik motifs can increase the potential of the creative industry in the textile sector for the people of the province of North Sumatra.

The results of this study are not only valid economically, but also have an impact on the culture of the Indonesian nation in developing the batik textile industry. Previous research by Suliyati \& Yulianti (2019) on the development of Semarang batik motifs for strengthening Semarang's cultural identity, has played a role in increasing batik production. The increased production of batik in Semarang has made a positive contribution to the development of Kampung Batik and Kampung Djadoel. Therefore, the results of this study are expected to have the same contribution as Semarang batik, so that it can become the identity of the people of North Sumatra. 
Table-2. Details of the stylization of Batak and Malay batik motifs

\begin{tabular}{|c|c|c|c|c|}
\hline No. & $\begin{array}{l}\text { Motif } \\
\text { Name }\end{array}$ & Motif Shape & Color used & Dimension \\
\hline 1 & $\begin{array}{l}\text { Gorga } \\
\text { Boraspati }\end{array}$ & & - The color used in this motif is white & $\begin{array}{l}\checkmark \checkmark \text { Length } 4 \mathrm{~cm} \\
\checkmark \text { Width } 4.5 \mathrm{~cm}\end{array}$ \\
\hline 2 & $\begin{array}{l}\text { Bamboo } \\
\text { shoots }\end{array}$ & 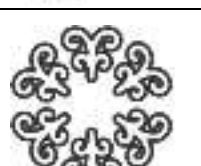 & $\begin{array}{l}\text { - The color used in this motif is golden } \\
\text { - Red } 20 \% \\
\text { - Yellow } 80 \%\end{array}$ & $\checkmark$ Diameter $8 \mathrm{~cm}$ \\
\hline 3 & $\begin{array}{l}\text { Ulos } \\
\text { Sadum }\end{array}$ & & $\begin{array}{l}\text { - Ulos sadum motif uses two colors, } \\
\text { namely yellow and orange } \\
\text { - Yellow } 100 \% \\
\text { - Red } 80 \% \\
\text { - Yellow } 60\end{array}$ & $\begin{array}{l}\checkmark \checkmark \text { Length } 3 \mathrm{~cm} \\
\checkmark \text { Width } 2.5 \mathrm{~cm} \\
\checkmark \text { Pattern line length adjusts }\end{array}$ \\
\hline 4 & Rattan & & - Rattan motif using yellow color & $\begin{array}{l}\checkmark \text { The length of the motif on } \\
\text { the left and right is } 2.5 \mathrm{~cm} \\
\checkmark \text { The length of the motif in } \\
\text { the middle } 3 \mathrm{~cm} \\
\checkmark \text { Width } 0.5 \mathrm{~cm}\end{array}$ \\
\hline
\end{tabular}

Another similar study by Nurcahyati \& Affanti (2018) on the development of contemporary batik designs based on regional potential and local wisdom, reveals that the position of contemporary batik as part of the national creative industry can be said to be one of the small and not dominant elements, but has quite an important place. Contemporary batik is more accurately described as a candidate for creative industry products and concepts that are prospective for the future.

UNESCO's recognition and appreciation of Indonesian batik as a Masterpieces of the Oral and Intangible Heritage of Humanity on October 2, 2009 encouraged people from various regions or cities to look for the characteristics of batik motifs. This has the potential to encourage the economy in the local and foreign tourism sector. Opening employment opportunities for local residents and reducing the unemployment rate of the local community and increasing regional per capita income.

The main formula has been found, namely the development of batik designs based on superior potential and local wisdom that can survive to face global or international market competition. The concern that batik cannot last long because it is still limited to standards, rules and traditions and is far from modernity is not well-founded. Batik does not have to be made into a piece of cloth, but can be in the form of elements contained in it, such as its philosophical meaning, process, and decorative patterns. The form or model of product differentiation can use an existing concept. But the new design will produce a different look. Like a new painting, even if it is applied to stone, t-shirts, walls, or broken glass, it will still be interesting because there is a new concept that has never been presented before.

\section{CONCLUSION}

Based on the results of the study, it can be concluded that the level of feasibility of developing Batak and Malay batik motifs in the province of North Sumatra obtained an average validation value of 0.89 , which indicates the product is feasible to be developed in improving the creative industry. The results of the product development of stylized Batak and Malay batik motifs in the province of North Sumatra were made by classifying the 
length of the material as $200 \mathrm{~cm}$ and the width of the fabric as $110 \mathrm{~cm}$. The color of the basic material used is blue, the color of the stylized bamboo shoots motif, and golden yellow gorga boraspati. Ulos sadum motif uses three colors, namely yellow, light yellow, and orange. Rattan motifs use three colors, namely light blue, light yellow and light brown.

\section{REFERENCES}

Aiken, L. R. (1985). Three coefficients for analyzing the reliability and validity of ratings. Educational and psychological measurement, 45(1), 131-142.

Arifin, E. N., Ananta, A., Wilujeng W. U. D. R., Budi H. N., \& Pramono, A. (2015). Quantifying Indonesia's ethnic diversity: statistics at national, provincial, and district levels. Asian Population Studies, 11(3), 233-256.

Azwar, S. (2014). Dasar-dasar psikometri. Yogyakarta: Pustaka Belajar.

BPS. (2010). Kewarganegaraan, Suku Bangsa, Agama, dan Bahasa Sehari-hari Penduduk Indonesia. Jakarta: Badan Pusat Statistik.

Butar-Butar, K. (2018). The Aesthetic Study of Traditional Cloth North Sumatera. In International Conference on Business, Economic, Social Science and Humanities (ICOBEST 2018) (pp. 435-440): Atlantis Press.

Desy N., \& Tiwi B. A. (2018). Contemporary batik design development based on regional potency and local wisdom. Jurnal Sosioteknologi, 17(3), 391-342.

Jaya, I. (2020). Culture to serve barometer sustainability of North Sumatera and HANKAMNAS development in Indonesia. Britain International of Humanities and Social Sciences (BIoHS) Journal, 2(1), 148-159.

Kusumawardhani, R. (2012). Batik How to Wear. Jakarta: Gramedia.

Rajagukguk, H. V. (2020). Perancangan Kasula dan Stola dengan ide penggambaran Gorga Batak Toba melalui teknik batik tulis. Corak: Jurnal Seni Kriya, 9(1), 37-52.

Saad, A. A. (2006). Desar Desain Dwimatra. Makasar: Universitas Negeri Makasar.

Seels, B. B. \& Richey, R. C. (1994). Teknologi Pembelajaran: Definisi dan Kawasannya. Jakarta: Universitas Negeri Jakarta.

Sihite, L. (2021). The effect of village funds, Human Development Index (HDI), and economic growth on decrease of poverty level in North Sumatera Province. International Journal of Public Budgeting, Accounting and Finance, 4(1), 1-10.

Sihombing, N. S., \& Sihombing, A. (2018). The effect of business environment and innovation spirit on competitive advantages and implications on marketing performance of ulos weaving in North Sumatra. Journal of Environmental Management \& Tourism, 9(32), 1782-1788.

Sitompul, R. H. P. (2009). Ulos Batak Tempo Dulu - Masa Kini. Jakarta: Kerabat.

Hami, S., \& Suryawan, D S. (2009). Batik Jawa Barat. Jakarta: Gramedia.

Sudijono, A. (2009). Pengantar Statistik Pendidikan. Jakarta: Rajawali Press.

Sugiyono. S. (2009). Metode Penelitian Kuantitatif, Kualitatif dan R\&D. Bandung: Alfabeta.

Tambunan, S. B., Lores, L., \& Rosalina, D. (2019). Study of Factors Inhibiting the Business of Batik and Ulos Craftsmen in North Sumatra. In ICOFEB 2018: Proceedings of the 1st International Conference on Finance Economics and Business, ICOFEB 2018, 12-13 November 2018, Lhokseumawe, Aceh, Indonesia.

BBKB. (2018). Buku Penuntun Batik. Yogyakarta: Andi.

Suliyati T., \& Yuliati, D. (2019). Pengembangan motif batik semarang untuk penguatan identitas budaya Semarang. Jurnal Sejarah Citra Lekha, 4(1), 61-73.

Trianto, T. (2012). Model Pembelajaran Terpadu. Jakarta: Bumi Aksara. 